\title{
Nutrient status, plant availability and seasonal forcing mediate fish herbivory in temperate seagrass beds
}

\author{
Patricia Prado $^{1, *}$, Javier Romero ${ }^{2}$, Teresa Alcoverro ${ }^{3}$ \\ ${ }^{1}$ Institut de Recerca i Tecnología Agroalimentàries (IRTA), Aquatic Ecosystems, Carretera Poble Nou km 5.5, \\ 43540 Sant Carles de la Ràpita, Tarragona, Spain \\ ${ }^{2}$ Departamento de Ecología, Facultad de Biología, Universidad de Barcelona, Avenida Diagonal 645, 08028 Barcelona, Spain \\ ${ }^{3}$ Centro de Estudios Avanzados de Blanes, Carretera d'Accés a la Cala St. Francesc, 14, 17300 Blanes, Girona, Spain
}

\begin{abstract}
Among mechanisms for herbivore choice, palatability and abundance of food resources appear to have a central role in foraging ecology. Hence, nutrient supply due to eutrophication may cause profound alterations to both nutritional and quantitative aspects of primary producers, leading to changes in herbivory pressure and enhancing overall functional changes. We present an experiment of water column enrichment in an oligotrophic seagrass bed of Posidonia oceanica (northwestern Mediterranean Sea). In this study we measured monthly seasonal changes in fish herbivore behavior following alterations in qualitative (nutrient content, species composition) and quantitative (biomass availability) features of primary producers (seagrass, epiphytes and macroalgae) as a result of nutrient fertilization. Nutrient addition induced changes in both seagrass (enhanced plant $\mathrm{N}$ content and leaf growth) and epiphytes (enhanced N content, biomass load and altered species composition) throughout late spring and summer. This nutritional alteration of food organoleptic properties concurred within the seasonal peak of herbivory by the fish Sarpa salpa and caused a disproportionate herbivore pressure on enriched plots, until shoots were reduced to around $50 \%$ of their original leaf area. When plant biomass on fertilized plots was substantially reduced, herbivores fed mostly on control plots until the end of the summer period. During the rest of the year (autumn and winter), moderate nutrient additions could not disrupt the seasonal inertia of the ecosystem. Hence, our results show evidence that the foraging behavior of herbivorous fish is the result of chemical and visual sensing of the environment. Seasonal forcing, however, tightly controls ecosystem processes and the biological cycles of species, adding a further step to functional alterations in temperate seagrass meadows subjected to eutrophication.
\end{abstract}

KEY WORDS: Seasonality $\cdot$ Nutrient addition $\cdot$ Seagrass herbivory $\cdot$ Plant physiology $\cdot$ Epiphytes Sarpa salpa $\cdot$ Mediterranean

\section{INTRODUCTION}

The altered behavior of keystone herbivore species under eutrophication is a central process influencing diversity and abundance of primary producers and the overall functioning of ecosystems (e.g. Cambridge et al. 1986, Ruiz et al. 2001, Worm et al. 2002). However, the control exerted by herbivores is not simple or straightforward but may depend on inherent charac- teristics of ecosystems as well as on the ability of herbivore species to select for nutritional features of newly available resources. Burkepile \& Hay (2006) conducted a meta-analysis with 54 field experiments that orthogonally manipulated herbivore pressure and nutrient loading and found stronger herbivore effects in tropical oligotrophic regions, whereas in temperate systems effects were inconsistent, depending on the productivity of the system and the type of the dominant groups 
of macrophytes. Slow-growing species typically dominate in nutrient-poor regions or during seasons of poor nutrient availability, whereas fast-growing ephemeral species thrive in nutrient-rich areas (Taylor et al. 1995, Borum \& Sand-Jensen 1996). Therefore, it is critical to understand how additional nutrient loading to an ecosystem may modify key aspects of primary producers and the nutritional behavior of herbivores, as well as clarify the sensory mechanisms involved in the selection process. For instance, since herbivores seem to target fast-growing foliose species of macroalgae (Hughes et al. 1999, Thacker et al. 2001, Hays 2005), this may account for pervasive herbivore effects in low-productivity areas when influenced by short-term changes in nutrient availability. However, temperate regions are usually subjected to contrasting nutrient conditions and features of macrophytes are principally regulated by seasonal changes in light and temperature conditions (Alcoverro et al. 1995, Moore \& Wetzel 2000), which may account for inconsistent temporal and spatial effects on herbivore responses. In the case of seagrass systems, the outcome of nutrient-induced trophic interactions may be additionally complex since plants serve both as a food resource and as a substrate for epiphyte growth, particularly when an important amount of the leaf primary production is regularly consumed by herbivores (see review by Heck \& Valentine 2006).

Nutrient levels can modify seagrass through a sequence of flow-on effects at different levels that range from the physiological and individual level to compositional and biomass changes in macroalgae and epiphyte assemblages, which in turn may result in altered herbivory pressure (Romero et al. 2006). Nutrient addition has been observed to change nutritional properties of seagrass leaves and their epiphytes by increasing nutrient ratios (Moore \& Wetzel 2000), modifying plant defenses (Coley et al. 1985) or changing the composition of epiphyte assemblages (Prado et al. 2008a), which in turn can modify the palatability and/or structural properties of available food resources. However, compared with the well-studied role of terrestrial foliar $\mathrm{N}$ content in driving herbivore feeding preferences (e.g. Athey \& Connor 1989, Minkenberg \& Ottenheim 1990), the role of nutrients in seagrass leaves is often inconsistent (see review by Heck \& Valentine 2006), mainly because epiphytes offer an additional level of complexity to the nutritional properties. Seagrass consumption appears to be connected to modifications in the nutritional value of both epiphytes and seagrass leaves (Shepherd 1987, McGlathery 1995), but overall palatability may be complicated by the influence of changes in algal epiphyte composition (Gacia et al. 1999) and concentrations of chemical deterrents (Zapata \& McMillan 1979). Compensatory feeding strategies have also been identified for certain herbivores associated with variability in $\mathrm{N}$ concentration within food resources (reviewed by Mattson 1980) and may lead to decreased consumption rates of nutrient-rich plants (Valentine \& Heck 2001). In addition to modified seagrass palatability, nutrient levels can also affect herbivore behavior by changing the abundance and composition of other macrophyte species (i.e. enhanced biomass of rhizome algae and/or macroalgal mats). Since seagrasses have low C:N ratios (Duarte 1990) and contain a number of phenolic acids (Zapata \& McMillan 1979) and structural compounds, they are thought to be of poorer nutritional quality than macroalgae and experience lower herbivore attack (Cebrián 1999). On the other hand, different groups of herbivores may also respond to one or more types of cues from primary producers, depending on type and effectiveness of sensory organs involved in foraging behavior. For instance, herbivorous fishes and sea urchins, the most common macrograzers in seagrass beds, are known to rely on chemical signals to glean information from their environment (Adams et al. 1988, Hara 1994, Weissburg et al. 2002, Pillans et al. 2004). However, in addition to chemical sensing, fish largely rely on vision to locate and seize targeted food resources (Blaxter 1980). This may affect the strength and timing of topdown interactions following nutrient additions.

In the present study, we conducted a field fertilization experiment using the Mediterranean seagrass Posidonia oceanica to test the effect of nutrient seasonal forcing on the feeding behavior of the herbivorous fish Sarpa salpa (Sparidae). Shallow meadows of P. oceanica may lose up to $57 \%$ of the annual leaf production to the action of this herbivore (ca. $70 \%$ of herbivory) and the sea urchin Paracentrotus lividus (the remaining $30 \%$, Prado et al. 2007). The functioning of the system seems to be well adapted to nutrient-poor waters, and may be severely affected by coastal eutrophication, particularly during seasonal periods of external nutrient limitation (Alcoverro et al. 1995, 1997). Plants are nutrient-limited in late spring when leaf elongation is high, while luxuriant nutrient consumption and storage takes place during the winter period (Alcoverro et al. 1997). Seasonal trends for herbivory in shallow meadows attain maximum rates in summer (Tomas et al. 2005, Prado et al. 2007) whereas epiphyte composition is subject to seasonal succession (Ballesteros 1987), and both epiphyte biomass (Alcoverro et al. 1995) and macroalgal mats (Valiela et al. 1997) are maximal in spring-summer. Therefore, studies over 1 year in duration are necessary in order to understand how the effects of seasonal overlapping in the quality and availability of food resources modulate the outcome of interactions between plant and epiphyte nutrient content and herbivorous fish behavior in this temperate system. We added nutrients on a monthly basis to a 
shallow bed of $P$. oceanica over 1 yr to determine how nutrient levels affect physiological, individual and community aspects of primary producers (i.e. seagrass and epiphytes), and during which season the most relevant mechanisms controlling herbivore behavior take place. We examined the differences in S. salpa herbivory between control and enriched plots and related these to seagrass and epiphyte quality (nutrient content, species composition) and quantity (epiphytic biomass, plant availability) throughout the experiment.

\section{MATERIALS AND METHODS}

Study site. The study was conducted from May 2003 to June 2004 at a depth of $8 \mathrm{~m}$ in a Posidonia oceanica meadow formed by isolated and coalescent seagrass patches. The site was located near an open rocky shore off Fenals Cove, on the northeast Spanish (Catalonian) coast of the Mediterranean Sea (see a map of the study area in Gacia et al. 2009). Water column levels of nutrients in the area are relatively low, with annual averages of $0.96 \pm 0.07 \mu \mathrm{M}$ (mean $\pm \mathrm{SE}$ ) for nitrate and $0.29 \pm 0.04 \mu \mathrm{M}$ for phosphate (Cebrián et al. 1996). As a result, the study meadow is also characterised by low levels of leaf $\mathrm{N}$ content, with values that may be up to $45 \%$ lower than those found at other shallow locations along the Catalonian coast (Alcoverro et al. 1997, 2001).

In summer, the abundance of Sarpa salpa within the study meadow is somewhat greater than at other Catalonian locations (ca. 1 ind. $10 \mathrm{~m}^{-2}$ ) as a result of the fish's tendency to aggregate within vegetated patches (Prado et al. 2008b). In winter, fish abundance data are not available, but local herbivory pressure is known to be very low (Prado et al. 2007).

Experimental design. The seasonal influence of nutrient availability in fish herbivore behavior and the food quality and quantity was investigated by water column fertilization of 6 plots of Posidonia oceanica. An additional 6 plots were selected as controls. In all cases, plot size was approximately $3 \mathrm{~m}^{2}$ and mean shoot density high enough $\left(729 \pm 15\right.$ shoots $\left.\mathrm{m}^{-2}\right)$ to prevent possible effects induced by monthly sampling. The distance between sampling units (plots) was at least $10 \mathrm{~m}$ to avoid possible undesirable interactions.

Fish herbivory pressure was measured in enriched and control plots throughout the year. Nutrient and control plots were also monitored for several potential plant and community responses to nutrient increases throughout the year, including food quality (nutrient content in the plant and epiphytes, epiphyte composition) and food quantity (plant and epiphyte biomass) variables.

Fertilization experiment. Our aim was to increase nutrient levels within the range of variability of values commonly observed along the Catalonian coast (Alcoverro et al. 1997, 2001) to ensure that loading rates were representative of actual inputs. Nutrients were added monthly with a mixture of dipotassium hydrogen phosphate anhydrous, sodium nitrate and ammonium chloride (Panreac) salts and the Osmocote universal fertilizer (ratio N:P:K, 14:13:13). The salts cocktail (i.e. nitrate, ammonium and phosphate) was mixed with equal quantities of sand and poured into $200 \mathrm{ml}$ plastic containers. Separate $200 \mathrm{ml}$ containers were filled with Osmocote fertilizer. The containers were attached to a buoy on one end and to a large picket on the other end and drilled with 20 lateral holes ( $2 \mathrm{~mm}$ diameter) to allow a slow release of nutrients into the water column at the canopy height. The salts mixture released most of the nutrients in approximately $1 \mathrm{wk}$ (as determined in a laboratory trial). For the Osmocote fertilizer, dissolution of nutrients is temperature-dependent, but common seasonal ranges at the study site (ca. 13 to $25^{\circ} \mathrm{C}$, Cebrián et al. 1996) can provide a significant release for over 1 mo (Heck et al. 2000). A combination of the 6 salt nutrient and 3 Osmocote fertilizer containers were placed in each plot after sample collection. Based on the laboratory trials, the combination of both methods (nutrient containers and Osmocote) is estimated to provide a nutrient load of ca. $4 \mathrm{~g} \mathrm{NO}_{3}$ and $1 \mathrm{~g} \mathrm{PO}_{4} \mathrm{~m}^{-2} \mathrm{~d}^{-1}$. This load is comparable with monthly nutrient enrichment experiments conducted by Alcoverro et al. (1997), which caused an average increase of ca. $17 \%$ in leaf $\mathrm{N}$ content. No decreased water clarity in the form of either particulate matter or phytoplankton blooms was observed at any time as a result of the nutrient fertilization.

Field sampling. Each month, 3 replicate shoots at least $60 \mathrm{~cm}$ distance from each other were collected per plot before the fertilization kit was replaced. These shoots were used to measure plant and epiphyte quality (nutrient content and species composition) and quantity (biomass).

Fish herbivore pressure. Leaf losses to fish herbivory were estimated as the mean difference in shoot length between successive months when new bite marks were noted and corrected for leaf elongation. Since 3 random shoots were removed monthly from each plot, each of the new values was subtracted from former shoot lengths (i.e. 3 shoots) to give a total of 9 replicate measures. In addition, plant growth was estimated 3 times during the experimental period: June 2003, March 2004 and June 2004. We marked 5 shoots per plot in both experimental and control sites by puncturing the leaf bases with a hypodermic needle (Romero 1989). The marked shoots were collected a month later, and growth was estimated as the difference in length between the leaf base and the leaf scars. For the remaining periods of the year, leaf elongation 
was complemented with data recorded at the study site by Alcoverro et al. (1997) on a previous nutrient enrichment experiment. The possible error incurred by including broken leaves or sea urchin herbivory was also corrected for by subtracting the proportional loss of tissue caused by the observed frequency of breakage marks or sea urchin marks. However, Sarpa salpa was by far the main seagrass herbivore at the study site during the summer period (see Prado et al. 2008b) and the presence of broken leaves and sea urchin marks was low compared with the number of fish marks. Sea urchin marks increased in spring and winter (Prado et al. 2007), but no significant differences in leaf herbivory between treatments were detected during that period (see Results).

Shoot area and epiphyte biomass. The total leaf area of shoots (commonly 5 leaves) that was readily available for herbivore consumption was determined monthly on 3 randomly collected shoots per plot. For each leaf in a shoot, leaf length and width (in $\mathrm{cm}^{2}$ ) was measured and added to estimate total shoot area. Epiphytic biomass on seagrass leaves was determined monthly from the same shoots per plot. Epiphytes were carefully removed from leaves by scraping them off with a razor blade, dried at $60^{\circ} \mathrm{C}$ for $48 \mathrm{~h}$ and weighed.

Nutrient content in plants and epiphytes. The percentage carbon $(\% \mathrm{C})$ and nitrogen $(\% \mathrm{~N})$ content present in leaves and epiphytes were measured in the previous samples. The dried samples were ground and nutrient content $(\% \mathrm{C}$ and $\% \mathrm{~N})$ was determined in leaves and epiphytes separately with an EA 1108 CHNS-O Carlo Erba Analyser at the Serveis Cientificotècnics (SCT-UB), University of Barcelona.

Epiphyte composition. Epiphytic biomass on seagrass leaves was determined monthly from 3 additional randomly collected shoots per plot. Epiphytes were carefully removed from leaves by scraping them off with a razor blade, dried at $60^{\circ} \mathrm{C}$ for $48 \mathrm{~h}$ and weighed. Epiphytic composition on the oldest Posidonia oceanica leaf was determined to the species level in 3 additional shoots per plot (see Prado et al. 2008a for a detailed list of species).

Data analysis. The influence of nutrient supply on fish herbivory, leaf $\mathrm{N}$ content and shoot length was investigated with a 2-way ANOVA design (Plot, random nested in Treatment, fixed) for each month of the experiment. This design was conducted to avoid confounding effects due to significant autocorrelation between sampling months (presumably due to the clonal structure of the plant and restricted plot size) and to circumvent violations of multivariate analysis of variance (MANOVA) assumptions. In contrast, as no autocorrelation between months was observed for univariate epiphytic variables (presumably due to the short life span of epibiota), epiphytic biomass and $\mathrm{N}$ content were both investigated using a 3-way mixed ANOVA with Plot (random) nested within Treatment (fixed, fertilized versus control) and Month (fixed), as in Prado et al. (2008a).

In all analyses, data were transformed when necessary to meet ANOVA assumptions of normality (chisquared test) and homogeneity of variances (Cochran's test). However, in some instances assumptions were not met by transformation and the level of significance was fixed at $\mathrm{p}<0.01$ to minimize the possibility of making a Type II error (Underwood 1997). StudentNewman-Keuls (SNK) post hoc comparisons were used when necessary to investigate the existence of significant groups. Trends in taxonomic composition of epiphytic assemblages between treatments were investigated for each month with non-metric multidimensional scaling (NMDS) using the PRIMER software package (Clarke \& Warwick 2001). Leaf cover values of species were square-root transformed before analysis and then used to build a Bray-Curtis (BC) dissimilarity matrix.

\section{RESULTS}

\section{Fish herbivore pressure}

Grazing rates of Sarpa salpa were strongly seasonal, peaking in summer, and differed considerably between treatments for most of the year (Table 1, Fig. 1). Differences were especially striking in July, when leaf loss to herbivores was $40 \%$ higher in nutrient-enriched plots than in control plots; however, this trend was inverted in August and September (Fig. 1). During the year, some plot effects were also detected indicating smallscale variability in feeding behavior, but they were not significant during the months of heavier herbivory (Table 1). From October until the end of the experiment, herbivore pressure was once again higher in nutrient-enriched plots than in control plots, but with low rates of herbivory. The same seasonal patterns were observed when herbivory was expressed in terms of the percentage of primary production that was lost to S. salpa. Herbivory:production ratios displayed values that largely exceeded primary production during summer (up to 6-fold in fertilized plots in July, Fig. 1).

\section{Nutrient content in plants and epiphytes}

Percent $\mathrm{N}$ content in seagrass leaves was significantly higher in nutrient-enriched plots than in control plots from June to December 2003 and then again in June 2004 (Table 2, Fig. 2a). In nutrient-enriched plots, as well as in controls, monthly trends followed the sea- 
Table 1. Posidonia oceanica. 2-way ANOVA on fish herbivory pressure at each month of the experiment. ${ }^{*} \mathrm{p}<0.05,{ }^{* *} \mathrm{p}<$ $0.01,{ }^{* * *} \mathrm{p}<0.001$. Cochran's $C$ was not significant except in July, August and December 2003 and in May and June 2004

\begin{tabular}{|c|c|c|c|c|}
\hline \multirow[t]{2}{*}{ Month } & \multirow{2}{*}{$\begin{array}{l}\text { Source of } \\
\text { variation }\end{array}$} & \multicolumn{3}{|c|}{ Fish herbivory pressure } \\
\hline & & df & $\mathrm{MS}$ & F \\
\hline \multicolumn{5}{|l|}{2003} \\
\hline \multirow[t]{3}{*}{ Jun } & Treatment $=\mathrm{T}$ & 1 & 0.3125 & 0.723 \\
\hline & Plot $=\mathrm{P}(\mathrm{T})$ & 10 & 0.4319 & $2.64^{* *}$ \\
\hline & Error & 96 & 0.1636 & \\
\hline \multirow[t]{3}{*}{ Jul } & Treatment $=\mathrm{T}$ & 1 & 25.550 & $43.29^{* * *}$ \\
\hline & Plot $=\mathrm{P}(\mathrm{T})$ & 10 & 0.5901 & 0.849 \\
\hline & Error & 96 & 0.6952 & \\
\hline \multirow[t]{3}{*}{ Aug } & Treatment $=\mathrm{T}$ & 1 & 11.758 & $11.87^{*}$ \\
\hline & Plot $=\mathrm{P}(\mathrm{T})$ & 10 & 0.99048 & $2.74^{* *}$ \\
\hline & Error & 96 & 0.3610 & \\
\hline \multirow[t]{3}{*}{ Sep } & Treatment $=\mathrm{T}$ & 1 & 0.94167 & 1.37 \\
\hline & Plot $=\mathrm{P}(\mathrm{T})$ & 10 & 0.6870 & $4.21^{* * *}$ \\
\hline & Error & 96 & 0.1630 & \\
\hline \multirow[t]{3}{*}{ Oct } & Treatment $=\mathrm{T}$ & 1 & 1.5039 & 2.53 \\
\hline & Plot $=\mathrm{P}(\mathrm{T})$ & 10 & 0.5932 & $3.81^{* * *}$ \\
\hline & Error & 96 & 0.1555 & \\
\hline \multicolumn{5}{|l|}{2004} \\
\hline \multirow[t]{3}{*}{ Dec } & Treatment $=\mathrm{T}$ & 1 & 0.1280 & 1.98 \\
\hline & Plot $=\mathrm{P}(\mathrm{T})$ & 10 & 0.006443 & 2.11 \\
\hline & Error & 96 & 0.0304 & \\
\hline \multirow[t]{3}{*}{ Mar } & Treatment $=\mathrm{T}$ & 1 & 0.1507 & 2.57 \\
\hline & Plot $=\mathrm{P}(\mathrm{T})$ & 10 & 0.0584 & $9.03^{* * *}$ \\
\hline & Error & 96 & 0.0064 & \\
\hline \multirow[t]{3}{*}{ May } & Treatment $=\mathrm{T}$ & 1 & 0.0319 & 0.32 \\
\hline & Plot $=\mathrm{P}(\mathrm{T})$ & 10 & 0.1356 & $20.74^{* * *}$ \\
\hline & Error & 96 & 0.0065 & \\
\hline \multirow[t]{3}{*}{ Jun } & Treatment $=\mathrm{T}$ & 1 & 0.179115 & $22.15^{* * *}$ \\
\hline & Plot $=\mathrm{P}(\mathrm{T})$ & 10 & 0.008085 & 1.32 \\
\hline & Error & 96 & 0.0060 & \\
\hline
\end{tabular}

Table 2. Posidonia oceanica. 2-ways ANOVA for $\% \mathrm{~N}$ in leaves for each study month. ${ }^{*} \mathrm{p}<0.05,{ }^{* *} \mathrm{p}<0.01,{ }^{* * *} \mathrm{p}<0.001$. Cochran's $C$ was not significant except in July 2003

\begin{tabular}{|c|c|c|c|c|}
\hline Month & $\begin{array}{l}\text { Source of } \\
\text { variation }\end{array}$ & $\begin{array}{c}\% \mathrm{~N} \text { ir } \\
\mathrm{df}\end{array}$ & $\begin{array}{c}\text { Posidon } \\
\text { MS }\end{array}$ & $\begin{array}{c}\text { oceanica } \\
\text { F }\end{array}$ \\
\hline \multicolumn{5}{|l|}{2003} \\
\hline May & $\begin{array}{l}\text { Treatment }=\mathrm{T} \\
\text { Plot }=\mathrm{P}(\mathrm{T}) \\
\text { Error }\end{array}$ & $\begin{array}{r}1 \\
10 \\
24\end{array}$ & $\begin{array}{l}0.002 \\
0.022 \\
0.018\end{array}$ & $\begin{array}{l}0.106 \\
1.192\end{array}$ \\
\hline Jun & $\begin{array}{l}\text { Treatment }=\mathrm{T} \\
\text { Plot }=\mathrm{P}(\mathrm{T}) \\
\text { Error }\end{array}$ & $\begin{array}{r}1 \\
10 \\
24\end{array}$ & $\begin{array}{l}0.909 \\
0.023 \\
0.007\end{array}$ & $\begin{array}{l}40.16^{* * *} \\
2.9^{*}\end{array}$ \\
\hline Jul & $\begin{array}{l}\text { Treatment }=\mathrm{T} \\
\text { Plot }=\mathrm{P}(\mathrm{T}) \\
\text { Error }\end{array}$ & $\begin{array}{r}1 \\
10 \\
24\end{array}$ & $\begin{array}{l}0.560 \\
0.030 \\
0.011\end{array}$ & $\begin{array}{c}18.85^{* * *} \\
2.57\end{array}$ \\
\hline Aug & $\begin{array}{l}\text { Treatment }=\mathrm{T} \\
\text { Plot }=\mathrm{P}(\mathrm{T}) \\
\text { Error }\end{array}$ & $\begin{array}{r}1 \\
10 \\
24\end{array}$ & $\begin{array}{l}0.033 \\
0.01 \\
0.0004\end{array}$ & $\begin{array}{l}41.67^{* * *} \\
2.05\end{array}$ \\
\hline Sep & $\begin{array}{l}\text { Treatment }=\mathrm{T} \\
\text { Plot }=\mathrm{P}(\mathrm{T}) \\
\text { Error }\end{array}$ & $\begin{array}{r}1 \\
10 \\
24\end{array}$ & $\begin{array}{l}0.745 \\
0.010 \\
0.0051\end{array}$ & $\begin{array}{c}76.51^{* * *} \\
1.91\end{array}$ \\
\hline Oct & $\begin{array}{l}\text { Treatment }=\mathrm{T} \\
\text { Plot }=\mathrm{P}(\mathrm{T}) \\
\text { Error }\end{array}$ & $\begin{array}{r}1 \\
10 \\
24\end{array}$ & $\begin{array}{l}0.449 \\
0.030 \\
0.0171\end{array}$ & $\begin{array}{c}14.75^{* * *} \\
1.77\end{array}$ \\
\hline Dec & $\begin{array}{l}\text { Treatment }=\mathrm{T} \\
\text { Plot }=\mathrm{P}(\mathrm{T}) \\
\text { Error }\end{array}$ & $\begin{array}{r}1 \\
10 \\
24\end{array}$ & $\begin{array}{l}0.678 \\
0.013 \\
0.0158\end{array}$ & $\begin{array}{l}50.53^{* * *} \\
0.85\end{array}$ \\
\hline 2004 & & & & \\
\hline Mar & $\begin{array}{l}\text { Treatment }=\mathrm{T} \\
\text { Plot }=\mathrm{P}(\mathrm{T}) \\
\text { Error }\end{array}$ & $\begin{array}{r}1 \\
10 \\
24\end{array}$ & $\begin{array}{l}0.000 \\
0.097 \\
0.0145\end{array}$ & $\begin{array}{l}0.004 \\
6.696^{* * *}\end{array}$ \\
\hline May & $\begin{array}{l}\text { Treatment }=\mathrm{T} \\
\text { Plot }=\mathrm{P}(\mathrm{T}) \\
\text { Error }\end{array}$ & $\begin{array}{r}1 \\
10 \\
24\end{array}$ & $\begin{array}{l}0.000 \\
0.031 \\
0.0169\end{array}$ & $\begin{array}{l}0.010 \\
1.824\end{array}$ \\
\hline Jun & $\begin{array}{l}\text { Treatment }=\mathrm{T} \\
\text { Plot }=\mathrm{P}(\mathrm{T}) \\
\text { Error }\end{array}$ & $\begin{array}{r}1 \\
10 \\
24\end{array}$ & $\begin{array}{l}0.912 \\
0.018 \\
0.0160\end{array}$ & $\begin{array}{c}49.81^{* * *} \\
1.14\end{array}$ \\
\hline
\end{tabular}

Fig. 1. Posidonia oceanica. Rates of herbivory on seagrass expressed as leaf area loss $\left(\mathrm{cm}^{2} \mathrm{~d}^{-1}\right.$ shoot $\left.^{-1}\right)$ and herbivory:production ratios ( $\mathrm{H}: \mathrm{P}, \%)$ at each month of study in nutrientenriched plots (Nut) and control plots (Cont). For leaf area losses, significant differences between nutrient-enriched plots and control plots at each month of study are indicated by an asterisk

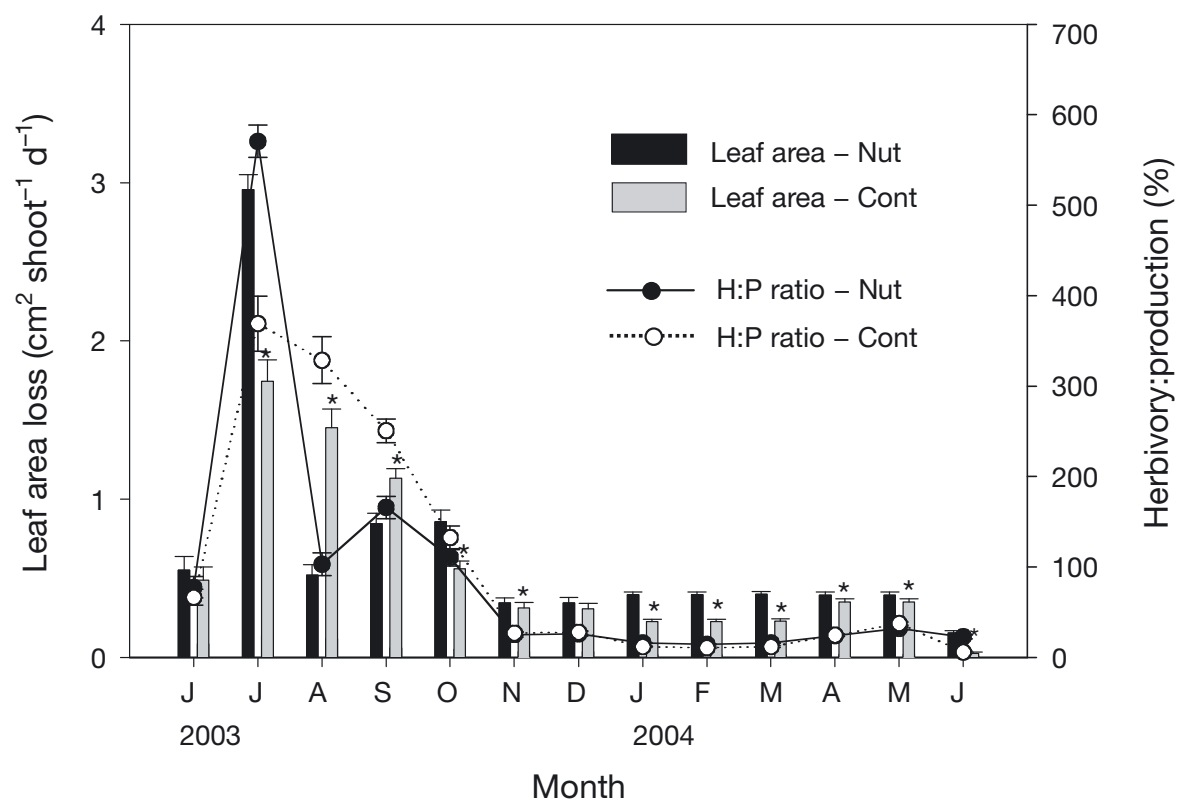



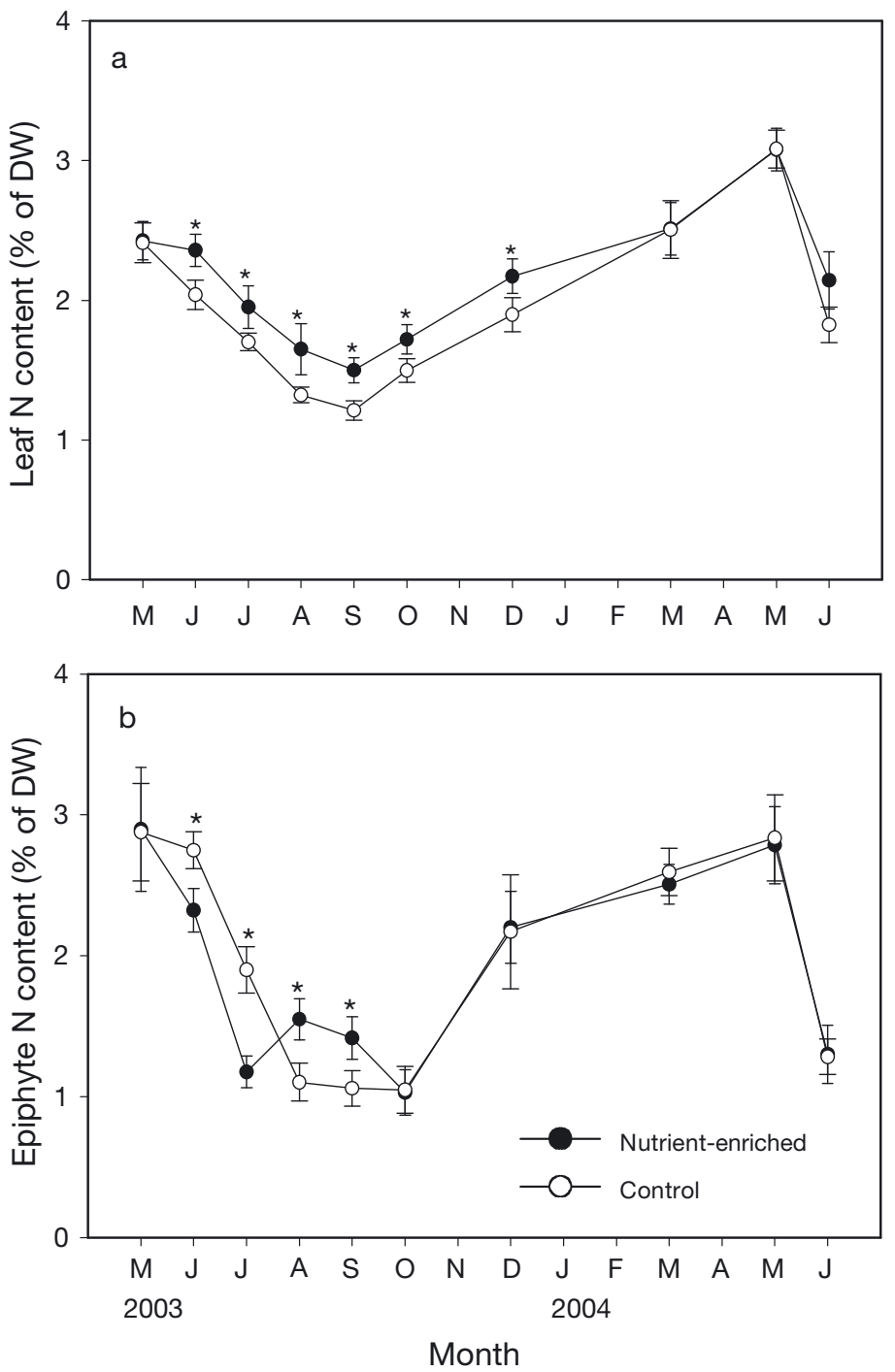

Fig. 2. Posidonia oceanica. Nitrogen content ( $\%$ of dry weight $[D W]$ ) in (a) seagrass leaves and (b) epiphytes recorded throughout the experiment. Statistically significantly differences between nutrient-enriched and control plots (SNK test) are indicated by an asterisk

sonal patterns described for Posidonia oceanica (Alcoverro et al. 1995) with the highest values occurring in spring (May 2003 and 2004) and the lowest during late summer (September 2003, Fig. 2a).

Percent $\mathrm{N}$ content of epiphytes was lower in nutrient-enriched plots than in control plots in June and July 2003, but was followed by a shift to higher values in nutrient-enriched plots in August and September 2003 (Treatment $\times$ Month interaction; Table 3a, Fig. 2b; SNK test, $\mathrm{p}<0.05)$. The major source of variance was the monthly trend, with the highest nutrient content in spring (May 2003 and 2004) and the lowest in early fall (October 2003).

\section{Epiphyte composition}

Epiphyte composition showed clear differences between treatments throughout the summer period (Fig. 3). In June and July, a large part of these differences was due to a decrease in cover of the bryozoan Electra posidoniae and the stimulation of a community of phaeophytes (e.g. Giraudia sphacelariodes and a number of Ectocarpaceae) in nutrient-enriched plots. In August and September, the phaeophytes Sphacelaria cirrhosa and Dictyota spp. were the dominant species in nutrient plots coupled with enhanced diversity of small Ceramiaceae (Prado et al. 2008a).

\section{Epiphyte biomass}

Epiphyte biomass responded to nutrient enrichment during mid- to late summer (i.e. August and September: $0.08 \pm 0.01$ and $0.02 \pm 0.005 \mathrm{~g}$ dry weight $(\mathrm{DW})$ shoot $^{-1}$ in fertilized and control plots, respectively, Table 3b, Fig. 3; SNK test, p < 0.05). However, the overall loads of epiphyte biomass achieved through experimental enrichment were very low and seasonality (differences among months) was the most important source of variability. In contrast, higher biomass values indicated large interannual differences in May 2004 compared with May 2003 (see Fig. 4).

\section{Total shoot area}

The amount of leaf material that was readily available for herbivore consumption differed substantially between treatments in the summer months of 2003 and the following spring (see Table 4) despite significantly

Table 3. Posidonia oceanica. 3-way ANOVA for \% N content in epiphytes and epiphytic biomass. ${ }^{*} \mathrm{p}<0.05,{ }^{* *} \mathrm{p}<0.01,{ }^{* * *} \mathrm{p}<0.001$. Cochran's $C$ was found to be not significant

\begin{tabular}{|lrrcrc|}
\hline \multirow{2}{*}{$\begin{array}{l}\text { Source of } \\
\text { variation }\end{array}$} & df & \multicolumn{2}{c}{$\%$ N in epiphytes } & \multicolumn{2}{c|}{ Epiphytic biomass } \\
& & \multicolumn{2}{c}{ MS } & $F$ & \multicolumn{2}{c|}{ MS } & $F$ \\
\hline Treatment = T & 1 & 0.171 & 2.28 & 0.0409 & $59.10^{* * *}$ \\
Plot $=\mathrm{P}(\mathrm{T})$ & 10 & 0.007 & 1.72 & 0.0007 & 0.74 \\
Month = M & 24 & 18.84 & $271.6^{* * *}$ & 0.3939 & $472.32^{* * *}$ \\
$\mathrm{~T} \times \mathrm{M}$ & 1 & 1.028 & $14.81^{* * *}$ & 0.0565 & $67.73^{* * *}$ \\
$\mathrm{P}(\mathrm{T}) \times \mathrm{M}$ & 10 & 0.069 & $1.59^{* *}$ & 0.0008 & 0.90 \\
Error & 24 & 0.044 & & 0.0009 & \\
& & & & & \\
\hline
\end{tabular}



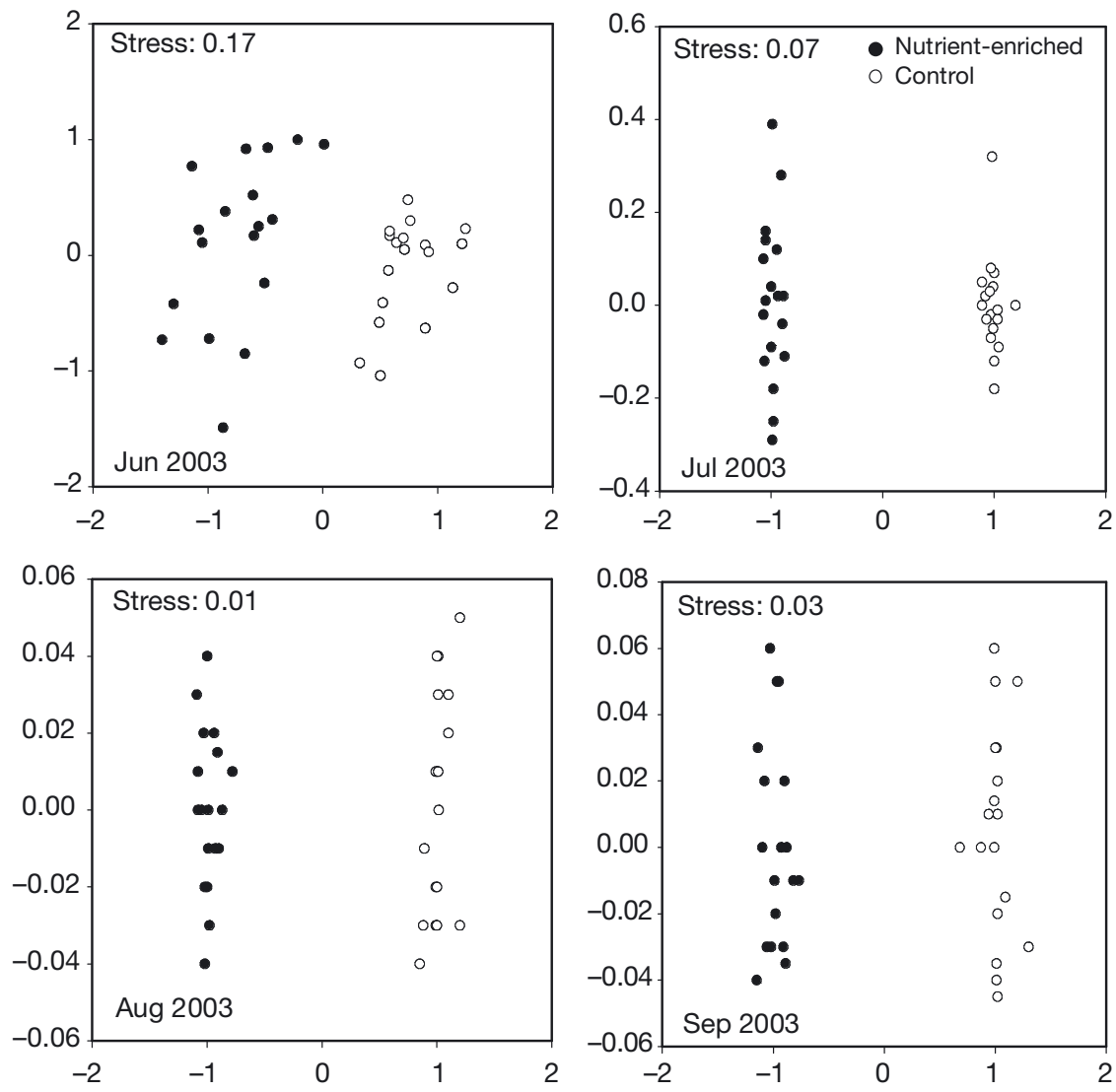

Fig. 3. Posidonia oceanica. Non-metric MDS plots showing differences in epiphytic assemblages on seagrass leaves between treatments during the period of fish herbivory (i.e. June to September). No significant differences were observed during the months before and after the summer period (for further details see Prado et al. 2008a) duced in the quality of primary producers, but only during the summer period. The nature of the behavioral changes was characterised by intense seagrass consumption from enriched plots early after the experiment started followed by a shift to feeding in control plots when the standing plant biomass had been reduced by about $50 \%$ of the initial shoot area. Hence, our results confirm previous findings that nutrient addition can enhance the overall palatability of seagrass leaves to consumers (Cambridge et al. 1986, Shepherd 1987, McGlathery 1995, Ruiz et al. 2001, Goecker et al. 2005), but additionally, they suggest that fish behavior is also controlled by resource availability. We propose that the foraging activity of $S$. salpa results from combined sensitivity and mobility abilities (visual, chemical, tactile or a combination of these) that improve exploitation efficiency according to concurring quality and availability features of the local resources. During the rest of the year, seasonal factors (light and temperature conditions) were a key factor controlling the turnover dynamics of epiphyte assemblages (see Ballesteros 1987) and the overall annual primary production of higher growth rates in nutrient-enriched plots. In July, total shoot area was considerably lower in nutrient-enriched plots than in control plots $(69.2 \pm 14.6$ and $108.7 \pm 22.4 \mathrm{~cm}^{2}$ shoot $^{-1}$, respectively), which coincided with the period of highest fish herbivory. These differences decreased throughout August and disappeared in September (Fig. 5). In contrast, significantly greater shoot areas were detected in nutrient-enriched plots than in control plots during May and June 2004, coinciding with the period of nutrient-limited plant growth.

\section{DISCUSSION}

The foraging behavior of Sarpa salpa was largely modified by the sequence of flow-on effects that nutrient addition in-

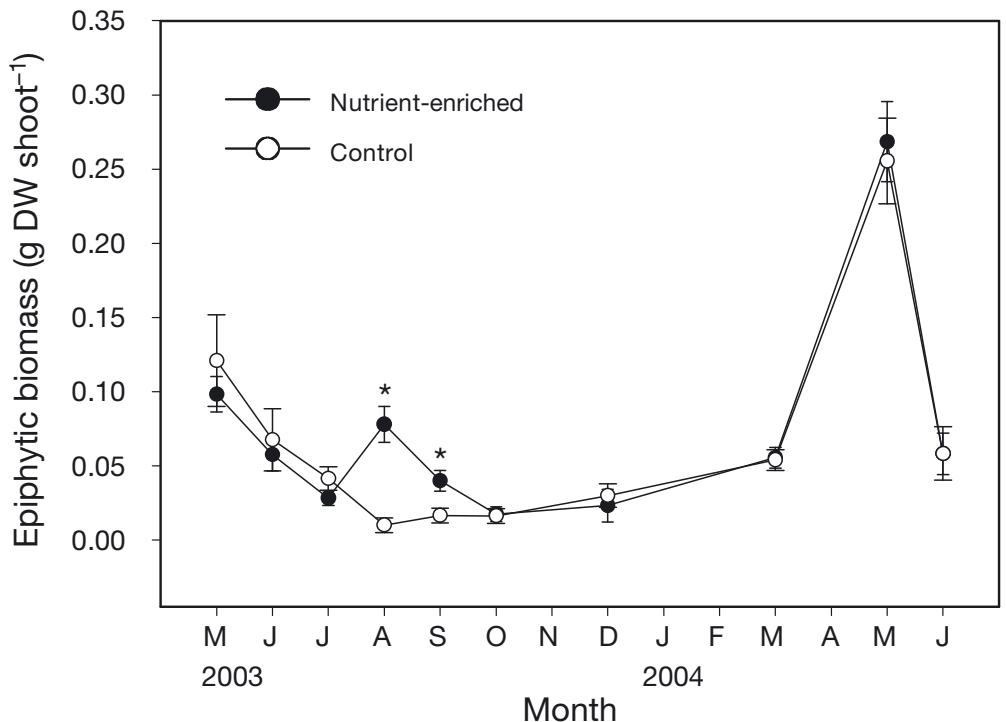

Fig. 4. Posidonia oceanica. Epiphytic biomass (g dry weight [DW] shoot ${ }^{-1}$ ) observed growing on control and nutrient-enriched plots at each month of the experiment. Significant differences are indicated by an asterisk 
Table 4. Posidonia oceanica. Results of 2-way ANOVA for total shoot area at each month of the experiment ${ }^{*} \mathrm{p}<0.05$, ${ }^{* *} p<0.01,{ }^{* * *} p<0.001$. Cochran's $C$ was not significant except in June 2004

\begin{tabular}{|c|c|c|c|c|}
\hline \multirow{2}{*}{ Month } & \multirow{2}{*}{$\begin{array}{l}\text { Source of } \\
\text { variation }\end{array}$} & \multicolumn{3}{|c|}{ Total shoot area $\left(\mathrm{cm}^{2}\right)$} \\
\hline & & $\mathrm{df}$ & MS & $F$ \\
\hline \multicolumn{5}{|l|}{2003} \\
\hline \multirow[t]{3}{*}{ May } & Treatment $=\mathrm{T}$ & 1 & 0.28 & 0.001 \\
\hline & Plot $=\mathrm{P}(\mathrm{T})$ & 10 & 59.1 & 0.141 \\
\hline & Error & 24 & 417.8 & \\
\hline \multirow[t]{3}{*}{ Jun } & Treatment $=\mathrm{T}$ & 1 & 52.3 & 0.146 \\
\hline & Plot $=P(T)$ & 10 & 358.6 & 0.691 \\
\hline & Error & 24 & 519.2 & \\
\hline \multirow[t]{3}{*}{ Jul } & Treatment $=\mathrm{T}$ & 1 & 14100 & $82.08^{* * *}$ \\
\hline & Plot $=\mathrm{P}(\mathrm{T})$ & 10 & 172 & 0.39 \\
\hline & Error & 24 & 437.8 & \\
\hline \multirow[t]{3}{*}{ Aug } & Treatment $=\mathrm{T}$ & 1 & 1572 & $13.99^{* * *}$ \\
\hline & Plot $=\mathrm{P}(\mathrm{T})$ & 10 & 396 & $3.52^{* *}$ \\
\hline & Error & 24 & 112.4 & \\
\hline \multirow[t]{3}{*}{ Sep } & Treatment $=\mathrm{T}$ & 1 & 13.9 & 0.05 \\
\hline & Plot = P (T) & 10 & 263.7 & $2.93^{*}$ \\
\hline & Error & 24 & 89.7 & \\
\hline \multirow[t]{3}{*}{ Oct } & Treatment $=\mathrm{T}$ & 1 & 4.07 & 0.086 \\
\hline & Plot $=\mathrm{P}(\mathrm{T})$ & 10 & 47.27 & 0.318 \\
\hline & Error & 24 & 148.6 & \\
\hline \multirow[t]{3}{*}{ Dec } & Treatment $=\mathrm{T}$ & 1 & 39.27 & 0.433 \\
\hline & Plot = P (T) & 10 & 90.63 & 1.098 \\
\hline & Error & 24 & 82.5 & \\
\hline \multicolumn{5}{|l|}{2004} \\
\hline \multirow[t]{3}{*}{ Mar } & Treatment $=\mathrm{T}$ & 1 & 34.8 & 0.155 \\
\hline & Plot $=\mathrm{P}(\mathrm{T})$ & 10 & 223.9 & 1.196 \\
\hline & Error & 24 & 187.7 & \\
\hline \multirow[t]{3}{*}{ May } & Treatment $=\mathrm{T}$ & 1 & 1131 & $6.00^{* * *}$ \\
\hline & Plot = P $(\mathrm{T})$ & 10 & 188 & $33.9^{*}$ \\
\hline & Error & 24 & 5.6 & \\
\hline \multirow[t]{3}{*}{ Jun } & Treatment $=\mathrm{T}$ & 1 & 646.9 & $4.628^{* * *}$ \\
\hline & Plot $=\mathrm{P}(\mathrm{T})$ & 10 & 139.8 & $13.53^{* * *}$ \\
\hline & Error & 24 & 10.3 & \\
\hline
\end{tabular}

al. 1997 for similar findings), thus indicating that experimental nutrient supply alleviated seasonal shortage during the summer period. Changes in leaf epiphytes between nutrient-enriched and control plots were evident in all investigated aspects of communities from late spring to late summer. Epiphyte assemblages were largely altered by the effects of the nutrient additions (see Prado et al. 2008a for a complete list of species), but species in both nutrient-enriched and control plots are commonly found in the stomach contents of Sarpa salpa (Verlaque 1987), thus dismissing the idea of chemicalmediated preference or deterrence. Atypical low values of epiphyte $\mathrm{N}$ content were observed in June and July, possibly due to compositional effects resulting from increased turnover of N-rich epifauna and the fast development of fastgrowing epiphytic algae under nutrient addition. Thus, enhanced early abundance of epiphytic algae might have, to some extent, triggered fish behavior during early summer. Later in the summer (August and September), $\mathrm{N}$ content and epiphytic biomass in control plots increased significantly, but this only occurred after the major episode of fish herbivory (see below). Although certain reduction of epiphytes may have occurred as a result of enhanced leaf consumption, epiphyte loads on leaves were still consistently low compared with other studies (e.g. Heck et al. 2000). In fact, seagrass appears to contribute to the diet of adult $S$. salpa to a greater extent than do epiphytes (see Havelange et al. 1997), and therefore, changes in seagrass quality itself possibly had a greater contribution in fish response. Surprisingly, neither treatment nor seasonal effects were observed on the development of macroalgal mats, possibly because of the relatively unexposed conditions of the study site. In fact, blooms of macro- the system (Alcoverro et al. 1995), and seasonal nutrient additions were not able to alter seasonal patterns of fish herbivory.

The qualitative properties of both plant (increased nutrient content) and epiphytes were simultaneously altered by monthly nutrient addition to Posidonia oceanica. Most of the changes in plant and epiphytes occurred simultaneously, so that early summer preferences for nutrient-enriched plots could have been induced by higher seagrass nutrient content (McGlathery 1995, Goecker et al. 2005), differential levels of plant defenses (Coley et al. 1985), modifications of the leaf epiphytic community (Gacia et al. 1999) or a combination of these factors. The highest leaf $\mathrm{N}$ content in nutrient-enriched plots was observed from June to December and then again the following spring (see Alcoverro et

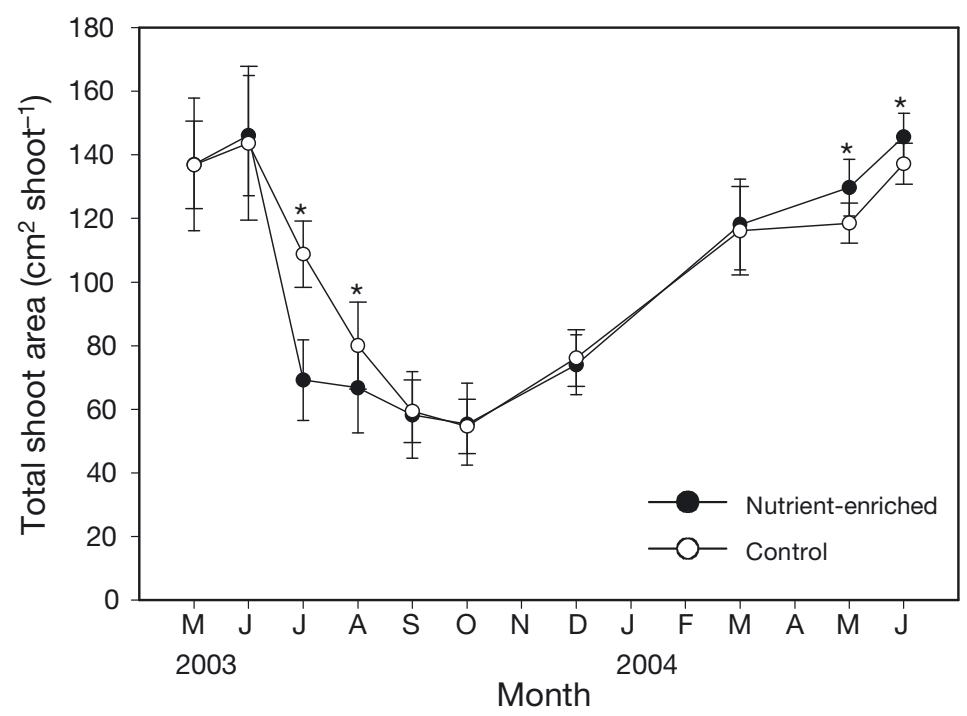

Fig. 5. Posidonia oceanica. Total shoot area $\left(\mathrm{cm}^{2}\right.$ shoot $\left.^{-1}\right)$ in control and nutrient-enriched plots during the experimental period. Significant differences between nutrient-enriched plots and control plots at each month of study are indicated by an asterisk 
algae are most often observed in sheltered sites, such as shallow bays and estuaries or coastal lagoons where water exchange with the offshore circulation is limited (e.g. Pedersen \& Borum 1996, Valiela et al. 1997).

Among mechanisms that influence choice, the presence and type of olfactory and gustatory receptors appear to be important features that drive foraging behavior of fish (review by Hara 1994) and strongly reflect their feeding ecology. For instance, the herbivorous fish Siganus fusenscens is equipped with receptors for a broad number of amino acids that may help the fish to discriminate between multiple species of macrophytes according to their nutrient content and assimilability features (Pillans et al. 2004). Herbivorous fish can also effectively detect other chemical components that would decrease feeding rates on seagrass leaves (Targett et al. 1986). However, no deterrence has yet been observed for Sarpa salpa (Vergés et al. 2007) and even defoliation does not seem to stimulate the production of inducible defenses in Posidonia oceanica (Vergés et al. 2008), though possible effects of resource availability in the production of secondary metabolites (Coley et al. 1985) are unknown. Since Sarpa salpa is a generalist herbivore (Verlaque 1987) possibly equipped with a similar chemosensory system to that previously described for Siganus fusenscens, enhanced plant $\mathrm{N}$ content and abundance of highly digestible epiphytic algae (Thayer et al. 1984) are the best candidate factors that explain preferential feeding on nutrient-enriched plots. Our results agree with previous observations that nutrient content (Heck et al. 2000, 2006, Goecker et al. 2005) and changes in epiphytic composition (Gacia et al. 1999) can stimulate leaf consumption by herbivorous fish, thus suggesting that nutrient-rich seagrass areas can be feeding grounds for mobile consumers (see also McGlathery 1995).

This situation was, however, unexpectedly reversed later in the summer (August and September) as fish performed preferential foraging incursions in control plots. To our knowledge, this shift in foraging behavior, possibly relying on the well-known ability of fish to detect visual cues (Blaxter 1980, Rowland 1999), has not yet been observed for other fish species. Yet, a similar type of feedback regulation of the standing biomass has been described for waterfowl. According to Charman (1979) and Tubbs \& Tubbs $(1982,1983)$, progressive shifts in the distribution and feedings habits of waterfowl species may arise when eelgrass Zostera spp. cover is reduced about 10 to $15 \%$, which triggers the exploitation of less preferred food resources. Similarly, the rapid (June and July) and dramatic decrease in plant standing biomass in nutrient-enriched plots (ca. $50 \%$ ) caused by nutrient supply may explain the shift in fish preference for the less exploited, neighbouring patches. This mechanism for choice was maintained throughout the remaining pe- riod of high herbivory (i.e. August and September; see Prado et al. 2007) and ended in fall after the regular association between the biological cycle and the seasonal habitat use in this species (Verlaque 1990). Fish responses to changes in nutrient availability may also be influenced by indirect effects mediated by landscape features as well as fish abundance (Prado et al. 2008b). The reduced seagrass area at the study site may have induced local populations of Sarpa salpa to concentrate within the seagrass patches. However, this situation may be reversed in extensive meadows of Posidonia oceanica where fish abundance is low and experimental enrichment causes enhanced leaf growth and mechanical breakage (Leoni 2005). Hence, a threshold of seagrass and fish abundance may be necessary to trigger changes in feeding behavior in eutrophic meadows. Further complex responses may also arise as a function of nutrient spread within the home range of $S$. salpa (ca. 4.3 ha according to Jadot et al. 2002) and/or the intensity of the effect, which could trigger enhanced availability of benthic macroalgae (Valiela et al. 1997) and possible feeding shifts.

To conclude, the capacity of fish to select for food resources and exert an effective control of excess primary production relies on a multiplicity of sensory traits, including olfactory and gustatory reception and visual cues. Therefore, both qualitative (plant N content) and quantitative (abundance of epiphytic algae and plant availability) availability of food resources are key features to understand possible alterations in the foraging behavior of herbivorous fishes, such as Sarpa salpa, induced by nutrient addition. Our results also indicate that in temperate seagrass beds the effects of nutrient additions on top-down control varies as a function of seasonality, which tightly regulates growth and diversity of primary producers.

Acknowledgements. This work was supported by a FI scholarship from the Departament d'Universitats, Recerca i Societat de la Informació (DURSI, Generalitat de Catalunya) and the CGL2007-66771-C02-xx/BOS project from the Spanish Ministry of Science and Technology. Element analyses were performed at the Serveis Científico-Tècnics de la Universitat de Barcelona. We are also grateful to B. Martinez, S. Mariani, T. Thibaut, F. Tomás and A. Vergés for fieldwork assistance during the experiment and to A. Rochette, G. Carreras, R. Cortés and M. Bardagí for help with the preparation of monthly nutrient containers. We also thank K. Heck for relevant comments that helped us to significantly improve the manuscript.

\section{LITERATURE CITED}

Adams MA, Johnsen PB, Hong-Qi Z (1988) Chemical enhancement of feeding for the herbivorous fish Tilapia zillii. Aquaculture 72:95-107

Alcoverro T, Duarte CM, Romero J (1995) Annual growth 
dynamics of Posidonia oceanica: contribution of largescale versus local factors to seasonality. Mar Ecol Prog Ser 120:203-210

> Alcoverro T, Romero J, Duarte CM, López N (1997) Spatial and temporal variations in nutrient limitation of seagrass Posidonia oceanica growth in the NW Mediterranean. Mar Ecol Prog Ser 146:155-161

Alcoverro T, Cebrián E, Ballesteros E (2001) The photosynthetic capacity of the seagrass Posidonia oceanica: influence of nitrogen and light. J Exp Mar Biol Ecol 261:107-120

Athey LA, Connor EF (1989) The relationship between foliar nitrogen content and feeding by Odontota dorsalis Thun. on Robinia pseudoacacia L. Oecologia 79:390-394

Ballesteros E (1987) Estructura i dinamica del poblament algal de les fulles de Posidonia oceanica. L. Delile als herbeis de Tossa de mar. Girona. Bull Inst Cat Hist Nat 54: $13-30$

Blaxter JHS (1980) Vision and the feeding of fishes. In: Bardach JE, Magnuson JJ, May RC, Reinhart JM (eds) Fish behavior and its use in the capture and culture of fishes. ICLARM Conf Proc 5:32-56

Borum J, Sand-Jensen K (1996) Is total primary production in shallow coastal marine waters stimulated by nitrogen loading? Oikos 76:406-410

Burkepile DE, Hay ME (2006) Herbivore versus nutrient control of marine primary producers: context-dependent effects. Ecology 87:3128-3139

Cambridge ML, Chiffings AW, Brittan C, Moore L, McComb AJ (1986) The loss of seagrass in Cockburn Sound, Western Australia. II. Possible causes of seagrass decline. Aquat Bot 24:269-285

Cebrián J (1999) Patterns in the fate of production in plant communities. Am Nat 154:449-468

Cebrián J, Duarte CM, Pascual J (1996) Marine climate on the Costa Brava (northwest Mediterranean) littoral. Publ Espec Inst Esp Oceanogr 22:9-21

Charman K (1979) Feeding ecology and energetics of the Dark-Bellied Brent goose Branta bernicla bernicla in Essex and Kent. In: Jefferies RL, Davies A (eds) Ecological processes in coastal environments. Blackwood, London, p 451-465

Clarke KR, Warwick RM (2001) Changes in marine communities: an approach to statistical analysis and interpretation. In: PRIMER-E, 2nd edn. PRIMER-E, Plymouth, p 172

> Coley PD, Bryant JP, Chapin FS III (1985) Resource availability and plant antiherbivore defense. Science 230:895-899

> Duarte CM (1990) Seagrass nutrient content. Mar Ecol Prog Ser 67:201-207

Gacia E, Littler MM, Littler DS (1999) An experimental test of the capacity of food web interactions (fish-epiphytes-seagrasses) to offset the negative consequences of eutrophication on seagrass communities. Estuar Coast Shelf Sci 48:757-766

Gacia E, Costalago D, Prado P, Piorno D, Tomas F (2009) Mesograzers in Posidonia oceanica meadows: an experimental approach to gastropod-epiphyte-seagrass interactions. Bot Mar 52:439-447

Goecker ME, Heck KL, Valentine JF (2005) Effects of nitrogen concentrations in turtlegrass Thalassia testudinum on consumption by the bucktooth parrotfish Sparisoma radians. Mar Ecol Prog Ser 286:239-248

- Hara TJ (1994) Olfaction and gestation in fish: an overview. Acta Physiol Scand 152:207-217

> Havelange S, Lepoint G, Dauby P, Bouquegneau JM (1997) Feeding of the sparid fish Sarpa salpa in a seagrass ecosystem: diet and carbon flux. PSZN I: Mar Ecol 18:289-297

Hays CG (2005) Effect of nutrient availability, grazer assem- blage and seagrass source population on the interaction between Thalassia testudimun (turtle grass) and its algal epiphytes. J Exp Mar Biol Ecol 314:53-68

Heck KL Jr, Valentine JF (2006) Plant-herbivore interactions in seagrass meadows. J Exp Mar Biol Ecol 330:420-436

Heck KL, Pennock JR, Valentine JF, Coen LD, Sklenar SA (2000) Effects of nutrient enrichment and small predator density on seagrass ecosystems: an experimental assessment. Limnol Oceanogr 45:1041-1057

Heck KL Jr, Valentine JF, Pennock JR, Chaplin G, Spitzer PM (2006) Effects of nutrient enrichment and grazing on shoalgrass Halodule wrightii and its epiphytes: results of a field experiment. Mar Ecol Prog Ser 326:145-156

Hughes T, Szmant AM, Steneck R, Carpenter R, Miller S (1999) Algal blooms on coral reefs: What are the causes? Limnol Oceanogr 44:1583-1586

Jadot C, Ovidio M, Voss J (2002) Diel activity of Sarpa salpa (Sparidae) by ultrasonic telemetry in a Posidonia oceanica meadow of Corsica (Mediterranean Sea). Aquat Living Resour 15:343-350

Leoni V (2005) Utilisation de Posidonia oceanica (L.) Delile dans le cadre de la surveillance du littoral: bilan des descripteurs-résponses face á un enrichissement en nutriments (N \& P). PhD thesis, l'Université de Corse

Mattson WJ (1980) Herbivory in relation to plant nitrogen content. Annu Rev Ecol Syst 11:119-161

> McGlathery KJ (1995) Nutrient and grazing influences on a subtropical seagrass community. Mar Ecol Prog Ser 122: $239-252$

Minkenberg O, Ottenheim J (1990) Effect of leaf nitrogen content of tomato plants on preference and performance of a leaf mining fly. Oecologia 83:291-298

Moore KA, Wetzel RL (2000) Seasonal variations in eelgrass Zostera marina L. responses to nutrient enrichment and reduced light availability in experimental ecosystems. J Exp Mar Biol Ecol 244:1-28

Pedersen MF, Borum J (1996) Nutrient control of algal growth in estuarine waters. Nutrient limitation and the importance of nitrogen storage among phytoplankton and species of macroalgae. Mar Ecol Prog Ser 142:261-272

$>$ Pillans RD, Franklin CE, Tibbetts IR (2004) Food choice in Siganus fuscences: influence of macrophyte nutrient content and availability. J Fish Biol 64:297-309

> Prado P, Tomas F, Alcoverro T, Romero J (2007) Extensive direct measurements of Posidonia oceanica defoliation confirms the importance of herbivory in temperate seagrass meadows. Mar Ecol Prog Ser 340:63-71

> Prado P, Alcoverro T, Romero J (2008a) Seasonal response of Posidonia oceanica epiphytic assemblages to nutrient increase. Mar Ecol Prog Ser 359:89-98

Prado P, Farina S, Tomas F, Romero J, Alcoverro T (2008b) Marine protection and meadow size alter fish herbivory in seagrass ecosystems. Mar Ecol Prog Ser 371:11-21

Romero J (1989) Primary production of Posidonia oceanica beds in the Medas Islands (Girona, NE Spain). In: Boudouresque CF, Meinesz A, Fresi E, Gravez V (eds) International workshop on Posidonia oceanica beds, Vol 2. GIS Posidonie, Marseille, p 83-86

Romero J, Lee KS, Pérez M, Mateo MA, Alcoverro T (2006) Nutrient dynamics in seagrass ecosystems. In: Larkum AWD, Orth RJ, Duarte DM (eds) Seagrasses: biology, ecology and conservation. Springer, Dordrecht, p 227-254

> Rowland WJ (1999) Studying visual cues in fish behavior: a review of ethological techniques. Environ Biol Fishes 56: 285-305

- Ruiz JM, Pérez M, Romero J (2001) Effects of fish farm loadings on seagrass (Posidonia oceanica) distribution, growth 
and photosynthesis. Mar Pollut Bull 42:749-760

Shepherd A (1987) Grazing by the sea urchin Paracentrotus lividus in Posidonia beds at Banyuls, France. In: Boudoureesque CF (ed) Colloque International sur Paracentrotus lividus et les oursins comestibles. GIS Posidonie, Marseille, p 83-86

Targett NM, Targett TE, Vrolijk NH, Ogden JC (1986) Effect of macrophyte secondary metabolites on feeding preferences of the herbivorous parrotfish Sparisoma radians. Mar Biol 92:141-148

Taylor DI, Nixon SW, Granger SL, Buckley BA, McMahon JP, Lin HJ (1995) Responses of coastal lagoon plant communities to different forms of nutrient enrichment-a mesocosm experiment. Aquat Bot 52:19-34

Thacker RW, Ginsburg DW, Paul VJ (2001) Effects of herbivory exclusion and nutrient enrichment on coral reef macroalgae and cyanobacteria. Coral Reefs 19:318-329

Thayer GW, Kenworthy WJ, Fonseca MS (1984) The ecology of eelgrass meadows of the Atlantic coast: a community profile. FWS/OBS-84/02, US Fish and Wildlife Service, Washington, DC

Tomas F, Turon X, Romero J (2005) Spatial and temporal variability of herbivory pressure on the temperate seagrass Posidonia oceanica L. Mar Ecol Prog Ser 301:95-107

Tubbs CR, Tubbs JM (1982) Brent geese Branta bernicla bernicla and their food in the Solent, Southern England. Biol Conserv 23:33-54

Tubbs CR, Tubbs JM (1983) The distribution of Zostera and its exploitation by wildfowl in the Solent, Southern England. Aquat Bot 15:223-239

Underwood AJ (1997) Experiments in ecology: their logical design and interpretation using analysis of variance. Cambridge University Press, New York

Editorial responsibility: Matthias Seaman, Oldendorf/Luhe, Germany
Valentine JF, Heck KL (2001) The role of leaf nitrogen content in determining turtlegrass (Thalassia testudinum) grazing by a generalized herbivore in the northeastern Gulf of Mexico. J Exp Mar Bio Ecol 258:65-86

Valiela I, McClelland J, Hauxwell J, Behr PJ, Hersh D, Foreman K (1997) Macroalgal blooms in shallow estuaries: controls and ecophysiological and ecosystem consequences. Limnol Oceanogr 42:1105-1118

> Vergés A, Becerro M, Alcoverro T, Romero J (2007) Variation in multiple traits of vegetative and reproductive seagrass tissues influences plant-herbivore interactions. Oecologia 151:675-686

> Vergés A, Pérez M, Alcoverro T, Romero J (2008) Compensation and resistance to herbivory in seagrasses: induced responses to simulated consumption by fish. Oecologia 155:751-760

Verlaque M (1987) Contribution a l'étude du phytobenthos d'un écosystème photopile thermophile marin en Méditerranée occidentale. Etude structurale et dynamique du phytobenthos et analyse des relations faune-flore. PhD thesis, Université d'Aix-Marseille II, Marseille

Verlaque M (1990) Relations entre Sarpa salpa (Linnaeus, 1758) (Teleosteen, Sparidae), les autres poissons brouteurs et le phytobenthos algal Méditerranéen. Oceanol Acta 13: 373-388

Weissburg MJ, Ferner CM, Pisut DP, Smee DL (2002) Ecological consequences of chemically mediated prey perception. J Chem Ecol 28:1953-1968

Worm B, Lotze HK, Hillebrand H, Sommer U (2002) Consumer versus resource control of species diversity and ecosystem functioning. Nature 417:848-851

- Zapata O, McMillan C (1979) Phenolic acids in seagrasses. Aquat Bot 7:307-317

Submitted: November 11, 2009; Accepted: March 15, 2010 Proofs received from author(s): June 3, 2010 